\title{
Article \\ Performance and Emissions of a Microturbine and Turbofan Powered by Alternative Fuels ${ }^{\dagger}$
}

\author{
Radoslaw Przysowa ${ }^{1, *} \mathbb{( D}$, Bartosz Gawron ${ }^{1}\left(\mathbb{D}\right.$, Tomasz Białecki ${ }^{1}\left(\mathbb{D}\right.$, Anna Łegowik ${ }^{1}\left(\mathbb{D}\right.$ and Jerzy Merkisz ${ }^{2}$ \\ and Remigiusz Jasiński ${ }^{2}$ (D) \\ 1 Instytut Techniczny Wojsk Lotniczych (ITWL), ul. Ksiecia Boleslawa 6, 01-494 Warsaw, Poland; \\ bartosz.gawron@itwl.pl (B.G.); tomasz.bialecki@itwl.pl (T.B.); anna.legowik@itwl.pl (A.Ł.) \\ 2 Faculty of Civil and Transport Engineering, Poznan University of Technology, ul. Piotrowo 3, \\ 60-965 Poznan, Poland; jerzy.merkisz@put.poznan.pl (J.M.); remigiusz.jasinski@put.poznan.pl (R.J.) \\ * Correspondence: radoslaw.przysowa@itwl.pl \\ $+\quad$ This paper is an extended version of our paper published in 10th EASN International Conference on \\ Innovation in Aviation \& Space to the Satisfaction of the European Citizens.
}

check for updates

Citation: Przysowa, R.; Gawron, B.; Białecki, T.; Łẹgowik, A.; Merkisz, J.; Jasiński, R. Performance and Emissions of a Microturbine and Turbofan Powered by Alternative Fuels. Aerospace 2021, 8, 25. https://doi.org/10.3390/ aerospace 8020025

Academic Editor: Spiros Pantelakis Received: 15 December 2020

Accepted: 15 January 2021

Published: 21 January 2021

Publisher's Note: MDPI stays neutral with regard to jurisdictional claims in published maps and institutional affiliations.

Copyright: (C) 2021 by the authors. Licensee MDPI, Basel, Switzerland. This article is an open access article distributed under the terms and conditions of the Creative Commons Attribution (CC BY) license (https:// creativecommons.org/licenses/by/ $4.0 /)$.

\begin{abstract}
Alternative fuels containing biocomponents produced in various technologies are introduced in aviation to reduce its carbon footprint but there is little data describing their impact on the performance and emissions of engines. The purpose of the work is to compare the performance and gas emissions produced from two different jet engines-the GTM-140 microturbine and the full-size DGEN380 turbofan, powered by blends of Jet A-1 and one of two biocomponents: (1) Alcohol-to-Jet (ATJ) and (2) Hydroprocessed Esters and Fatty Acids (HEFA) produced from used cooking oil (UCO) in various concentrations. The acquired data will be used to develop an engine emissivity model to predict gas emissions. Blends of the mineral fuel with synthetic components were prepared in various concentrations, and their physicochemical parameters were examined in the laboratory. Measurements of emissions from both engines were carried out in selected operating points using the Semtech DS gaseous analyzer and the EEPS spectrometer. The impact of tested blends on engine operating parameters is limited, and their use does not carry the risk of a significant decrease in aircraft performance or increase in fuel consumption. Increasing the content of biocomponents causes a noticeable rise in the emission of $\mathrm{CO}$ and slight increase for some other gasses $\left(\mathrm{HC}\right.$ and $\left.\mathrm{NO}_{x}\right)$, which should not, however, worsen the working conditions of the ground personnel. This implies that there are no contraindications against using tested blends for fuelling gas-turbine engines.
\end{abstract}

Keywords: turbofan; microturbine; sustainable aviation fuel; ATJ; HEFA; emissions; alternative fuel; biocomponent; combustion; fuel blend; drop-in fuel; synthesized kerosene

\section{Introduction}

In order to reduce $\mathrm{CO}_{2}$ emissions, as well as make use of inedible raw materials from renewable sources, alternative fuels containing biocomponents produced in various technologies are introduced in aviation [1-3]. However, there is much less experience in using biofuels to propel aircraft than in using mineral fuels. Currently, ASTM D 7566 standard allows for seven synthetic fuel production technologies to be used in aircraft turbine engines (Table 1), including Alcohol-to-Jet (ATJ) and Hydroprocessed Esters and Fatty Acids (HEFA). ATJ and HEFA belong to well-established sustainable aviation fuels (SAF) which do not require modifications in engines, aircraft or ground infrastructure (drop-in fuels) if used within the permissible mixing ratio.

Air-quality measurements clearly show that a single take-off or landing operation noticeably increases the concentration of toxic compounds in the air [4]. The widespread use of gas-turbine engines contributes to the deterioration of air quality in and around airports, and the negative impact of emitted gases and particles on health is of concern within ground personnel and neighbouring communities. Although emissions of all large 
engines are controlled during aircraft certification, the high intensity of air operations causes an accumulation of pollutants. Therefore, it is necessary to widely monitor air quality [5], especially in the vicinity of airports. After many years, the introduction of new rules for the certification of aircraft engines by ICAO (International Civil Aviation Organization) began, which is associated with the use of a new measurement methodology, which has been proposed in publications over the past years [6]. Recent research efforts [7] are aimed at measuring gaseous and particulate emissions under real conditions and better understanding their toxicity and impact on health [8-10].

Alternative fuels are expected not to increase emissions and provide a comparable or better engine performance. Blends with the ratio of biocomponents lower than the maximum allowable one are used mainly due to the higher cost of the alternative fuel or for fear of their impact on engine durability or performance. Therefore, when an alternative fuel is introduced into the fleet, the ratio of the biocomponent is gradually increased, observing its impact on the parameters and health of the engines.

New types of alternative fuels are synthesised in small quantities, insufficient to power large engines. This is why microturbines are often used to test new blends [11-14] despite the fact that their structure differs considerably from one of the commercial engine.

More and more often, scientific activity is focused on the development of models of emissions of toxic compounds from aviation [3] and their validation in real flight conditions and laboratory tests. To describe various fuels and blends, it is necessary to define their thermophysical parameters. In zero-dimensional models of engines, which are developed in GSP [15] or GasTurb [16,17], a simplified analytical description of combustion and tabulated values of temperature for fuel blends are often used. In the modelling of combustors, thermodynamic equations are used to describe combustion and heat transport $[18,19]$. When designing new combustors with reduced emissions, complex numerical CFD models are used [20,21]. An engine emissions data bank [22] and machine learning [23] models using statistical methods [24] or artificial intelligence are also used to predict emissions.

Table 1. Certified processes for Sustainable aviation fuel [25].

\begin{tabular}{llcc}
\hline Abbreviation & Conversion Process & Possible Feedstocks & Ratio \\
\hline FT-SPK & $\begin{array}{l}\text { Fischer-Tropsch hydroprocessed } \\
\text { synthesized paraffinic kerosene }\end{array}$ & $\begin{array}{c}\text { Coal, Natural Gas } \\
\text { Biomass }\end{array}$ & $\leq 50 \%$ \\
\hline HEFA-SPK & $\begin{array}{l}\text { Synthesized paraffinic kerosene produced } \\
\text { from hydroprocessed esters and fatty acids }\end{array}$ & $\begin{array}{c}\text { Bio-Oils, Animal Fat } \\
\text { Recycled Oils }\end{array}$ & $\leq 50 \%$ \\
\hline SIP & $\begin{array}{l}\text { Synthesized kerosene isoparaffins produced } \\
\text { from hydroprocessed fermented sugars }\end{array}$ & $\begin{array}{c}\text { Biomass used } \\
\text { for sugar production }\end{array}$ & $\leq 10 \%$ \\
\hline SPK/A & $\begin{array}{l}\text { Synthesized kerosene with aromatics } \\
\text { derived by alkylation of light aromatics }\end{array}$ & $\begin{array}{c}\text { Coal, Natural Gas } \\
\text { Biomass }\end{array}$ & $\leq 50 \%$ \\
\hline ATJ-SPK & $\begin{array}{l}\text { Alcohol-to-jet synthetic paraffinic kerosene } \\
\text { CHJ }\end{array}$ & $\begin{array}{c}\text { Biomass from ethanol } \\
\text { or isobutanol production }\end{array}$ & $\leq 50 \%$ \\
& $\begin{array}{l}\text { Catalytic Hydrothermolysis Jet from } \\
\text { processed fatty acid esters and fatty acids }\end{array}$ & $\begin{array}{c}\text { Triglycerides such as } \\
\text { soybean oil, jatropha oil }\end{array}$ & $\leq 50 \%$ \\
\hline HC-HEFA & $\begin{array}{l}\text { Synthesized paraffinic kerosene from hydro- } \\
\text { processed hydrocarbons, esters and } \\
\text { fatty acids }\end{array}$ & Algae & $\leq 10 \%$ \\
\hline
\end{tabular}

In this work, both a microturbine and full-size engine are used to generalise some results that can only be obtained with a microturbine. The purpose of the study is to compare the performance and gas emissions produced from two different jet engines- the GTM-140 microturbine and the DGEN380 geared turbofan. The acquired data will be used to develop an engine emissivity model to predict emissions of exhaust gas compounds. 


\section{Methods}

Blends of the mineral fuel with synthetic components were prepared in various concentrations and their physicochemical parameters were examined in the laboratory. The engines were powered by blends of Jet A- 1 and one of two biocomponents: (1) ATJ and (2) HEFA produced from used cooking oil (UCO). Measurements of gas emissions from the GTM-140 microturbine were carried out in selected operating points using the Semtech DS gaseous analyzer and the EEPS spectrometer. Similar emission measurements were made for the DGEN380 engine in a test cell. Measurements were averaged for each operating point, visualised and compared. Results were analyzed in the scope of physicochemical parameters of fuel blends, engine operating parameters and gas emissions (Figure 1).

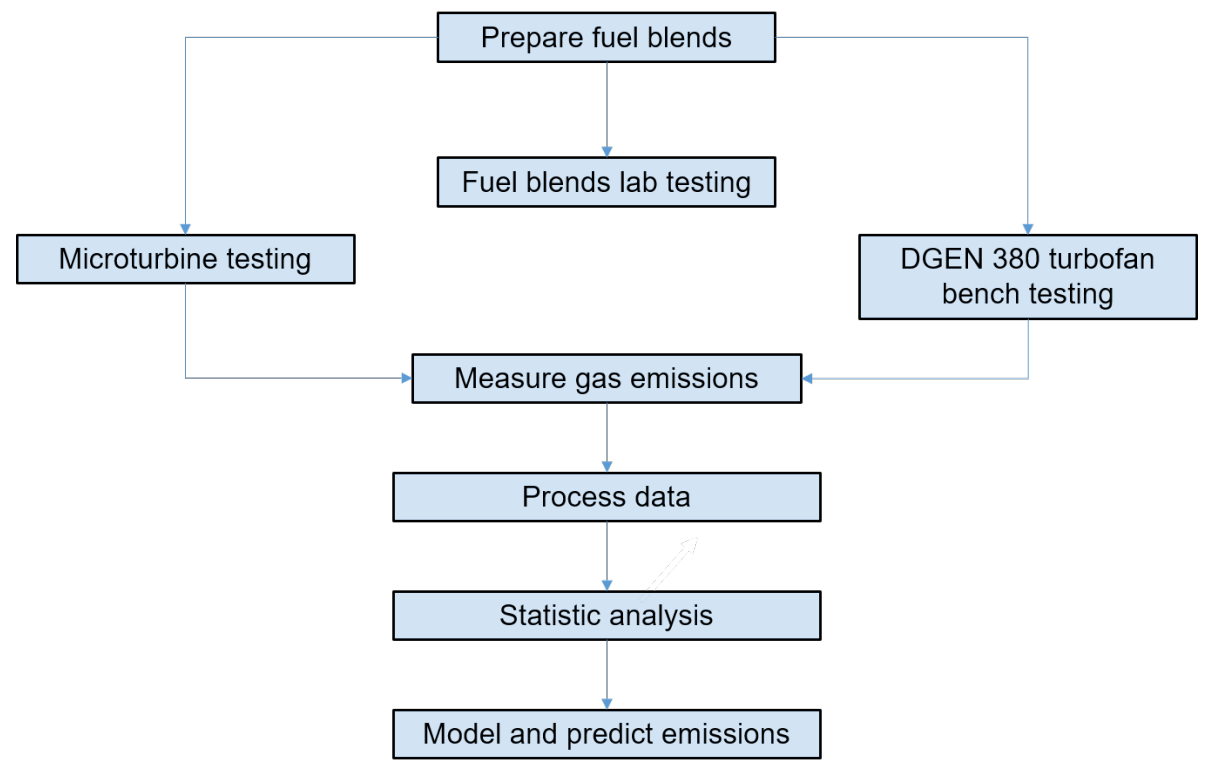

Figure 1. Testing methodology.

\subsection{Fuel Lab Testing}

In the fuel lab , physicochemical properties of prepared blends were tested such as: density at $15{ }^{\circ} \mathrm{C}$, viscosity at $-20^{\circ} \mathrm{C}$ and $-40{ }^{\circ} \mathrm{C}$, calorific value, the aromatics and naphthalenes content, flash point, crystallisation temperature, non-smoking smoke point and distillation. The selected properties are important for the combustion process and engine operation and are also defined in the ASTM D1655-18a and ASTM D7566-18 documents.

\subsection{GTM-140 Microturbine}

The GTM-140 microturbine (Figure 2) consists of a single-stage radial compressor, driven by a single-stage axial turbine, and an annular combustion chamber with a set of evaporators. It operates in the range of 33,000-120,000 rpm and can produce take-off thrust up to $140 \mathrm{~N}$. The tested variant of the microturbine played the role of a combustor rig and was devoid of a converging nozzle. For this reason, the generated thrust was limited to $70 \mathrm{~N}$, and consequently SFC values were high (above $200 \mathrm{~kg} / \mathrm{kN} / \mathrm{h}$ ). However, in this work, the absolute values of the parameters were less important than their relative changes in response to the increased biocomponent ratio. 


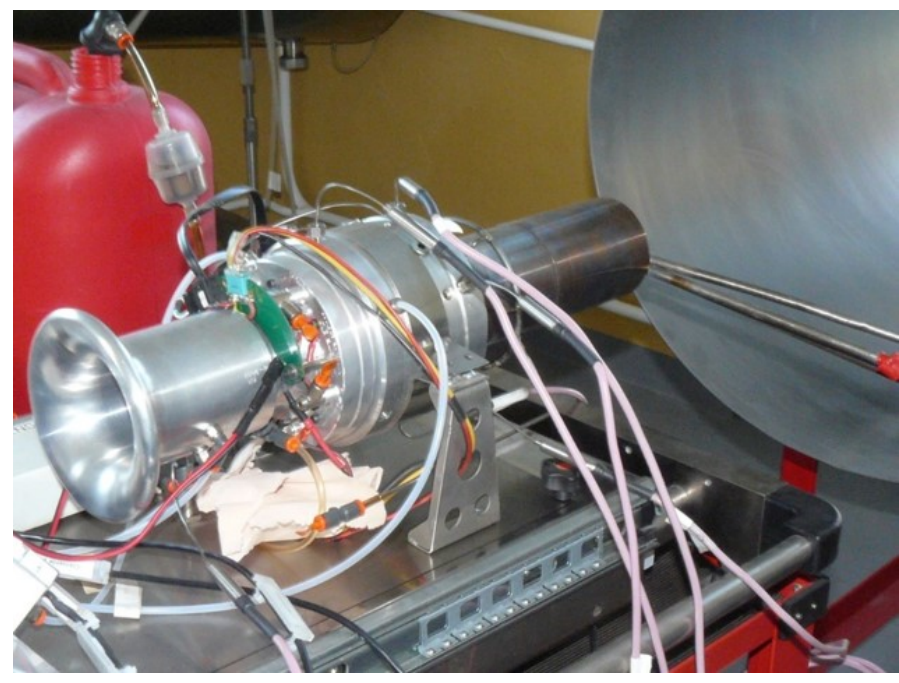

Figure 2. GTM-140 microturbine.

The test bench is equipped with a portable GA60 gas analyzer (Figure 3) which was used in previous emission research [26-28]. Exhaust gases are sampled from the engine nozzle using a probe and delivered through a heated exhaust hose to the instrument. The analyzer is equipped with electrochemical sensors to measure $\mathrm{O}_{2}, \mathrm{CO}, \mathrm{NO}, \mathrm{NO}_{2}, \mathrm{SO}_{2}$ gases and two NDIR (nondispersive infrared) sensors for infrared measurement $\left(\mathrm{CO}_{2}\right.$ and $\left.\mathrm{C}_{x} \mathrm{H}_{y}\right)$. The exhaust gas components are measured with the resolution of $0.1 \mathrm{ppm}$ and uncertainty of $5 \%$. The analyzer also enables the measurement of exhaust gas temperature through a thermocouple built inside the probe. Operating parameters and emissions are presented and stored by the data acquisition system developed in LabVIEW [29] Additionally, the Semtech DS gaseous analyzer (Figure 4) and Engine Exhaust Particle Sizer (EEPS 3090, Figure 5) operated by Poznan University of Technology were used with a respective exhaust sampling system (Figure 6). Exhaust gases were introduced to the Semtech DS analyzer through a probe maintaining the temperature of $191{ }^{\circ} \mathrm{C}$ and the exhaust sample was directed to the flame-ionizing detector (FID) where $\mathrm{HC}$ concentration was measured. Then the sample was cooled down to temperature of $4{ }^{\circ} \mathrm{C}$ and the concentration measurement of $\mathrm{NO}_{x}$ (NDUV analyzer), $\mathrm{CO}, \mathrm{CO}_{2}$ (NDIR analyzer) was performed. In the following sections, raw emission results expressed in ppm or percents are presented.

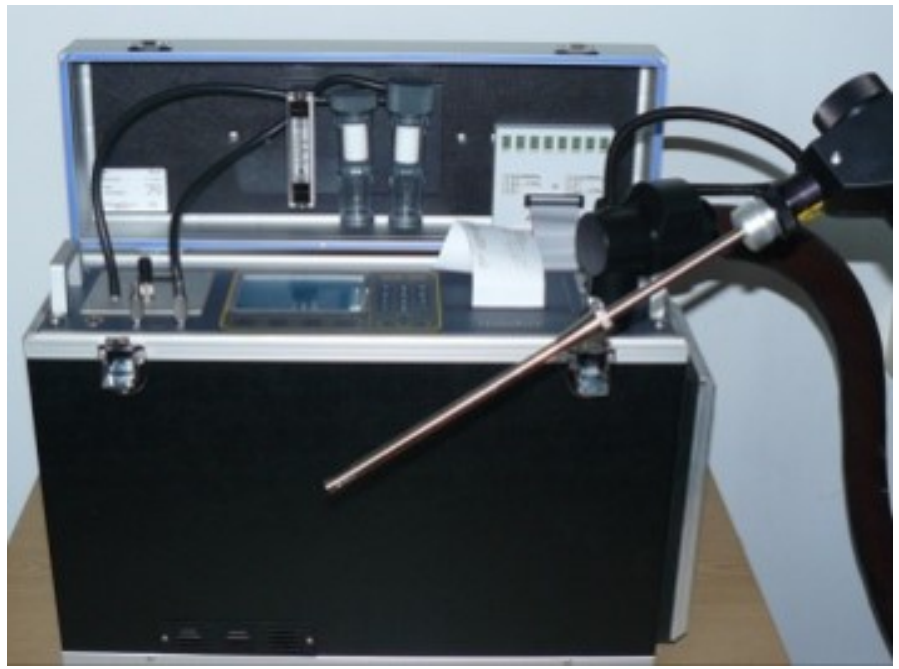

Figure 3. GA-60 emissions analyser. 


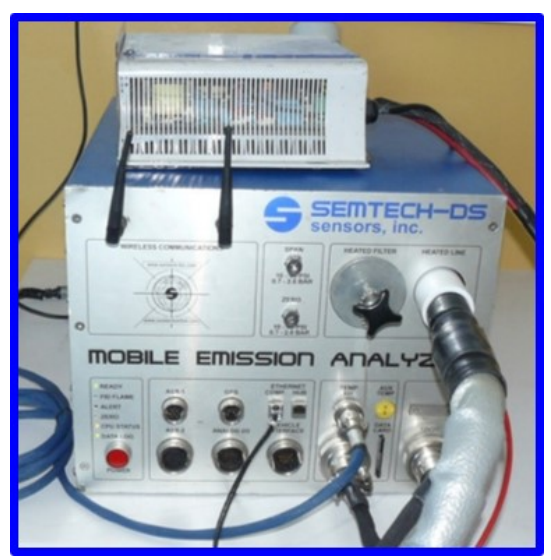

Figure 4. SEMTECH DS gaseous emission analyzer.

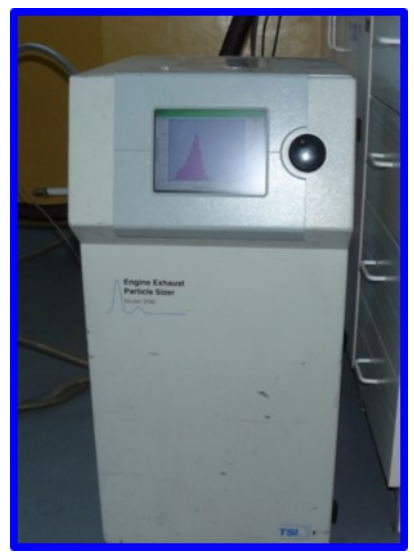

Figure 5. Engine Exhaust Particle Sizer (EEPS) 3090.

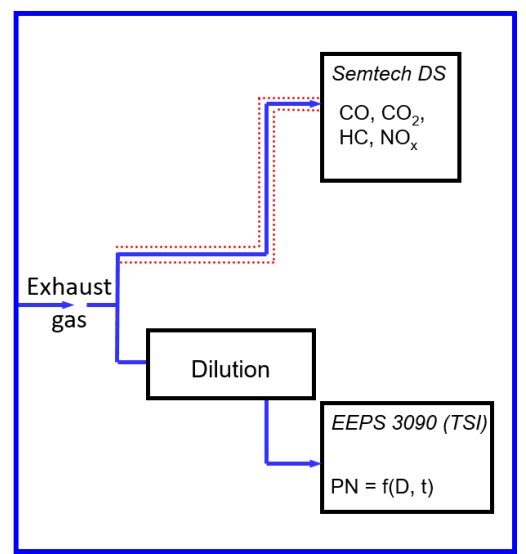

Figure 6. Exhaust gas sampling.

\subsection{DGEN 380 Turbofan}

DGEN 380 is a high bypass ratio (7.6) geared turbofan, producing $255 \mathrm{daN}$ of thrust (Figure 7). It has a layout similar to modern commercial engines, low fuel consumption and is well instrumented. The data acquisition system of the WESTT test cell (Figure 8) enables data acquisition and analysis of several engine performance parameter such as thrust, fuel consumption, temperature and pressure. The turbofan was developed for ultralight aircraft but has not been certified yet, so it is not covered by the ICAO emissions databank. In this work, the Semtech DS analyzer was used to measure $\mathrm{CO}, \mathrm{CO}_{2}, \mathrm{HC}$ and $\mathrm{NO}_{x}$ emissions. These are probably the first published results of gaseous emissions for this engine. 


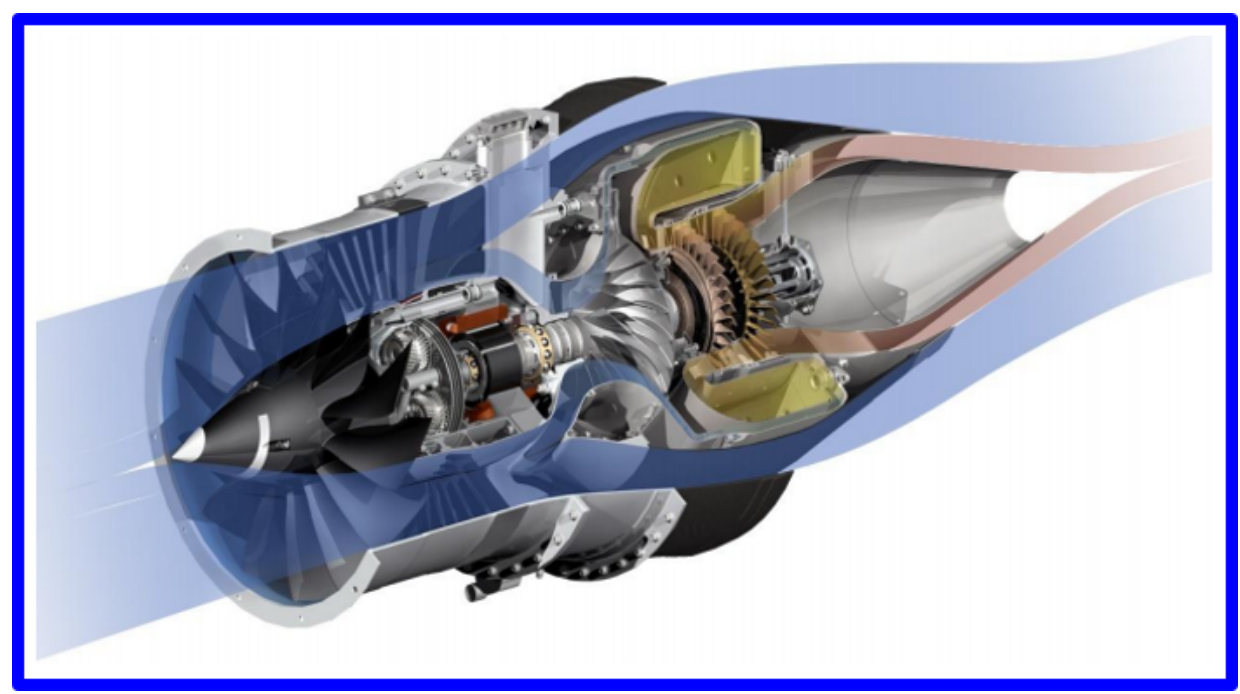

Figure 7. DGEN 380 geared turbofan.

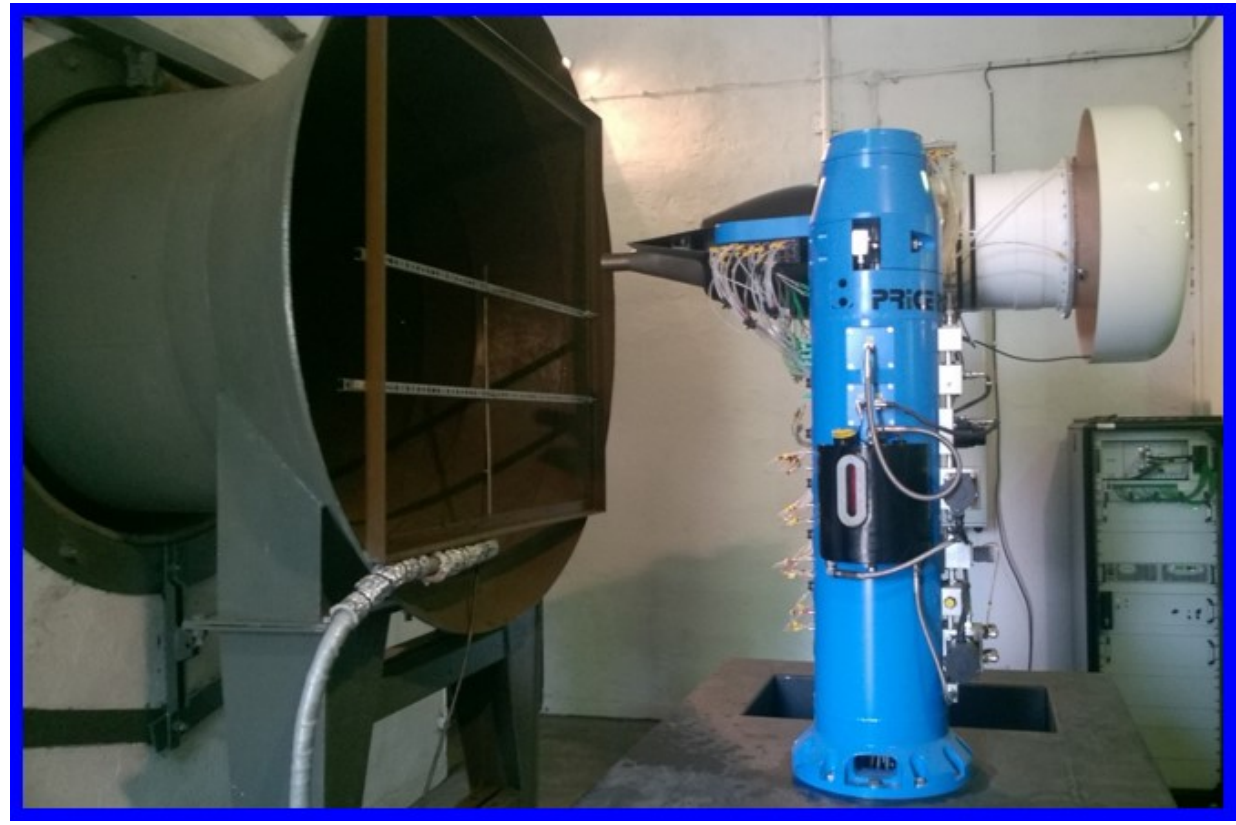

Figure 8. Test cell.

During tests of the DGEN380 turbofan with biocomponents, a finite amount of fuel in the tank was used to maintain a constant blend ratio throughout the test. This means that the tank was not constantly refilled with fuel as was the case with testing on the Jet A-1 fuel. With the tank almost empty, the flow resistance may have increased, but no lower fuel pressure was observed, nor was the fuel pump running at higher RPM. Nevertheless, it turned out that the fuel flow was slightly lower (by $2 \%$ ) and as a result, it the nominal thrust was not achieved, despite the PLA set at 100\% (Section 3.4).

\subsection{Engine Testing}

Engine emissions significantly depend on its operating mode (Figure 9), so they are tested in selected operating points that belong to the Landing and Take-Off cycle (LTO), according to the ICAO procedure [30]. Engine test steps correspond to the following operating modes: takeoff, climb, cruise, approach and taxi/ground idle. The tests performed on both types of engines consisted of a series of operating points, where the speed was increased in subsequent steps (Figure 10). Performance parameters and emissions were 
measured and averaged over $30 \mathrm{~s}$ for the microturbine and $60 \mathrm{~s}$ for the turbojet. The parameters are presented versus thrust which better represents LTO operating modes.

Tests with ATJ blends were performed one day under stable ambient conditions while tests with HEFA were performed one year later under similar conditions. The fuel was not switched during each test-run, so both startups and shutdowns were carried out on the same fuel as the main test. No problem was observed when starting or shutting down the microturbine on alternative fuels. In the case of the turbofan, restarting it after a shutdown was unsuccessful when it was fuelled with an ATJ blend. However, it was not caused by the fuel but by the low oil pressure due to air in the oil.

When comparing the individual blends, an identical mission profile was repeated, consisting of a series of operating points. Efforts were made to ensure that the rotational speeds were the same in subsequent tests, but it was difficult, especially for intermediate speeds. The engine operation range was selected using PLA and FADEC and it was not possible to fine-tune speed or thrust. There are slight but significant speed differences between the test-runs, which is especially important when analysing changes in engine performance.

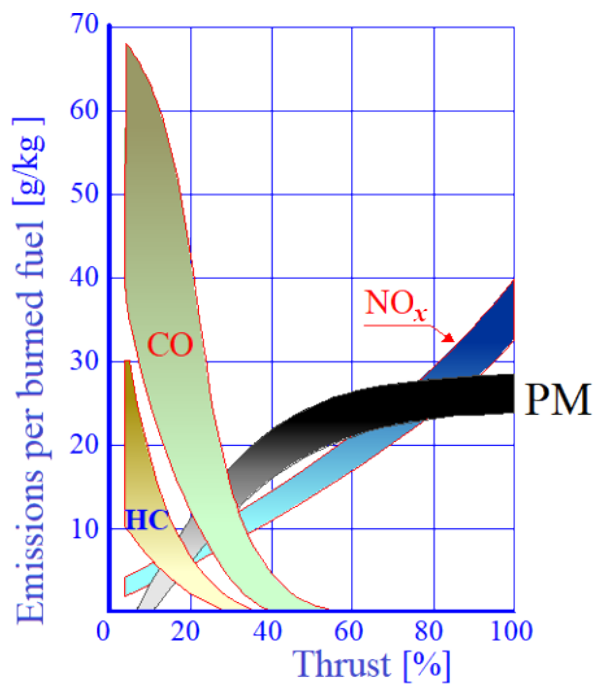

Figure 9. Emissions vs. thrust.

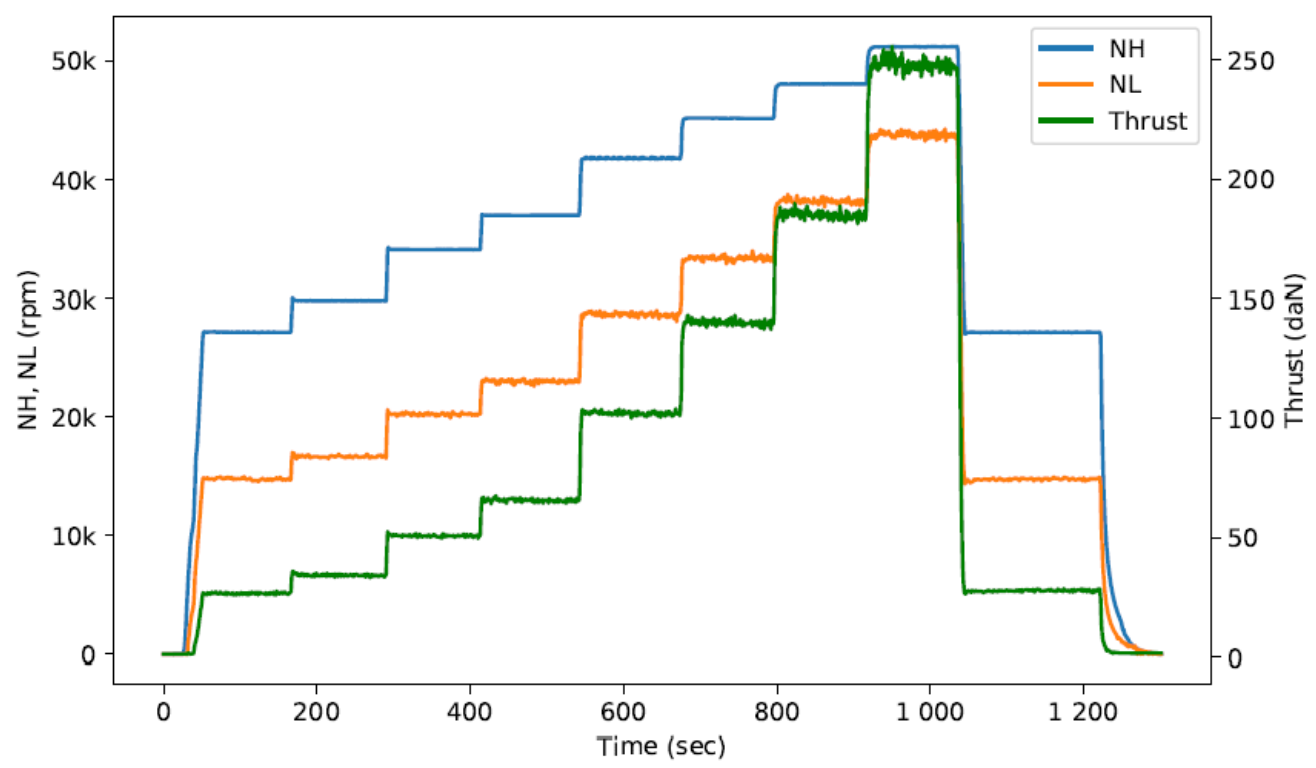

Figure 10. Engine test profile for DGEN 380. 
As the certified fuels were used in this project and the running time was short, the engines were not inspected for solid deposits or hot corrosion [31] after the testing. This can be done with a borescope or by stripping down the engine [32,33]. However, the DGEN 380 turbofan was tested later with Jet A-1 fuel without any problems while the microturbine has been continuously operated on various alternative fuels and regularly inspected when replacing the rotor bearings. No significant damage or deposits were observed in the hot section.

\section{Results}

\subsection{Fuel Lab Testing}

Lab testing confirmed that the mineral fuel meets the requirements of the ASTM D1655 standard, while ATJ and HEFA biocomponents and their blends comply with ASTM D7566. Table 2 presents the selected physicochemical properties of all tested fuels. The results show that neat biocomponents and their blends are characterised by a lower density than Jet A-1. This has an impact on fuel mass flow. Moreover, biocomponents have a slight higher calorific value, which may result in higher values of the produced heat and a higher EGT. As it is well known, higher combustion temperature increases $\mathrm{NO}_{x}$ emissions. Moreover, neat bio-components are free from aromatics which generally have the least desirable combustion characteristics among kerosene's major components.

Table 2. Fuel lab testing results.

\begin{tabular}{|c|c|c|c|c|c|c|c|c|}
\hline Fuel & $\begin{array}{c}\text { Density at } \\
15^{\circ} \mathrm{C} \mathrm{kg} / \mathrm{m}^{3}\end{array}$ & $\begin{array}{c}\text { Viscosity at } \\
-20^{\circ} \mathrm{C} \mathrm{mm}^{2} / \mathrm{s}\end{array}$ & $\begin{array}{c}\text { Calorific } \\
\text { Value } M J / k g\end{array}$ & $\begin{array}{l}\text { Aromatics } \\
(v / v) \%\end{array}$ & $\begin{array}{c}\text { Naphtha- } \\
\text { Lenes }(v / v) \%\end{array}$ & Flash Point ${ }^{\circ} \mathrm{C}$ & $\begin{array}{l}\text { Freezing } \\
\text { Point }{ }^{\circ} \mathrm{C}\end{array}$ & $\begin{array}{c}\text { Smoke Point } \\
\text { mm }\end{array}$ \\
\hline ASTM & $775-840$ & Max 8.0 & Min 42.8 & Max 25 & Max 3.0 & Min 38 & $\operatorname{Max}-40$ & Min 18 \\
\hline Jet A-1 & 798 & 3.40 & 43.2 & 16.7 & 0.58 & 49.5 & -63.5 & 20 \\
\hline $5 \%$ ATJ & 796 & 3.45 & 43.3 & 15.7 & 0.55 & 49.0 & -65.5 & 23 \\
\hline $20 \%$ ATJ & 790 & 3.57 & 43.4 & 13.0 & 0.46 & 49.0 & -66.5 & 25 \\
\hline $30 \%$ ATJ & 786 & 3.66 & 43.4 & 11.3 & 0.40 & 49.0 & -66.8 & 28 \\
\hline $50 \%$ ATJ & 776 & 3.65 & 43.6 & 8.8 & 0.27 & 44.5 & -60.0 & 30 \\
\hline ATJ & 759 & 4.78 & 44.0 & 0.0 & & 47.5 & -67.5 & \\
\hline Jet A-1 & 796 & 3.25 & & & 0.55 & 49 & -62.6 & 23 \\
\hline $5 \%$ HEFA & 794 & 3.29 & & & 0.52 & 48 & -62.8 & 27 \\
\hline $20 \%$ HEFA & 787 & 3.40 & & & 0.44 & 46 & -59.6 & 28 \\
\hline $30 \%$ HEFA & 783 & 3.47 & & & 0.39 & 46 & -56.0 & \\
\hline HEFA & 752 & 4.09 & 44.2 & & & 45 & -39.9 & \\
\hline
\end{tabular}

\subsection{Microturbine-ATJ}

During engine tests, the operating parameters such as thrust (Figure 11) and SFC (Figure 12) remain stable, with insignificant differences between tests. Plots below (Figures 13-16) present the $\mathrm{CO}, \mathrm{CO}_{2}, \mathrm{HC}$ and $\mathrm{NO}_{x}$ emissions of engine fuelled by blends with increasing ratio of the biocomponent (Jet A-1, 50\% blend of Jet A- 1 with the ATJ component and neat ATJ component). Values are averaged for $30 \mathrm{~s}$ while error bars show the triple standard deviation from the mean.

The results show that the addition of the ATJ component caused an increase in CO emissions compared to the Jet A-1 aviation fuel in all operating points (Figure 13). The greater the proportion of ATJ in the mixture, the greater the increase in $\mathrm{CO}$ emissions. In terms of $\mathrm{CO}_{2}$ emissions (Figure 14), ATJ component causes a slight decrease in $\mathrm{CO}_{2}$ emissions in relation to the neat Jet A-1 fuel.

In the case of HC emissions (Figure 15), the change in emissions of this parameter with the addition of the ATJ component is not conclusive. At the first two rotational speeds, an increase in $\mathrm{HC}$ emissions was obtained after adding the ATJ component in relation to Jet A-1. At three successive operating points, the addition of the ATJ component resulted in a decrease in $\mathrm{HC}$ emissions for the Jet A-1 fuel. 


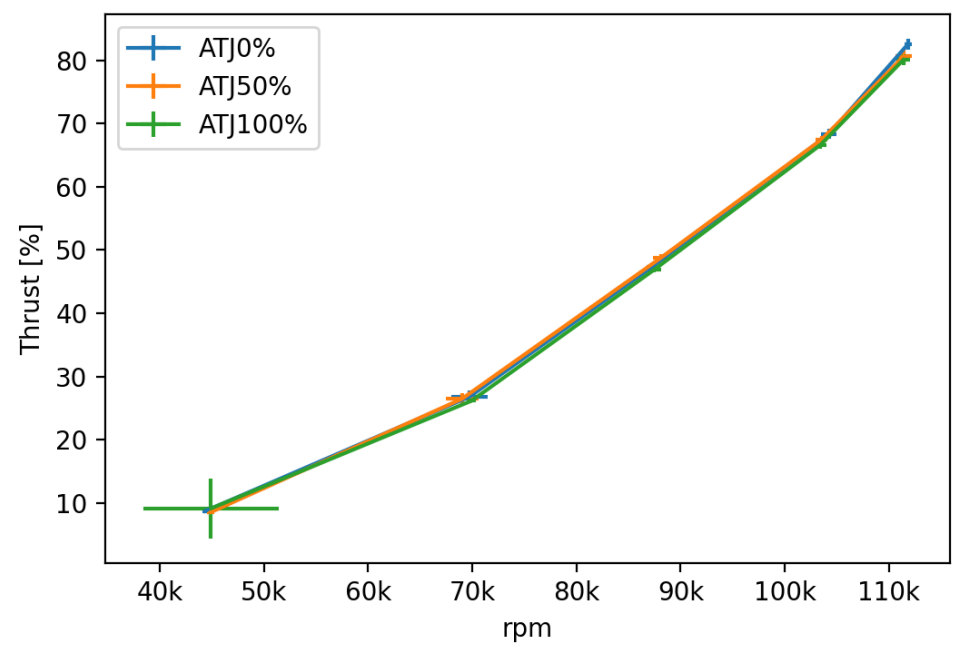

Figure 11. GTM-140/ATJ: Thrust.

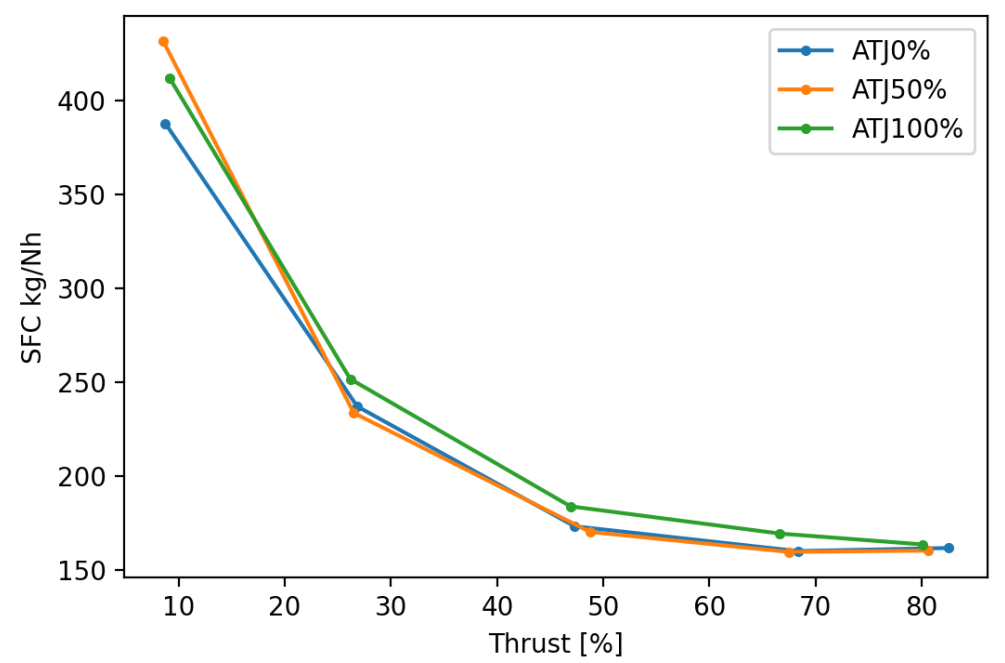

Figure 12. GTM-140/ATJ: SFC.

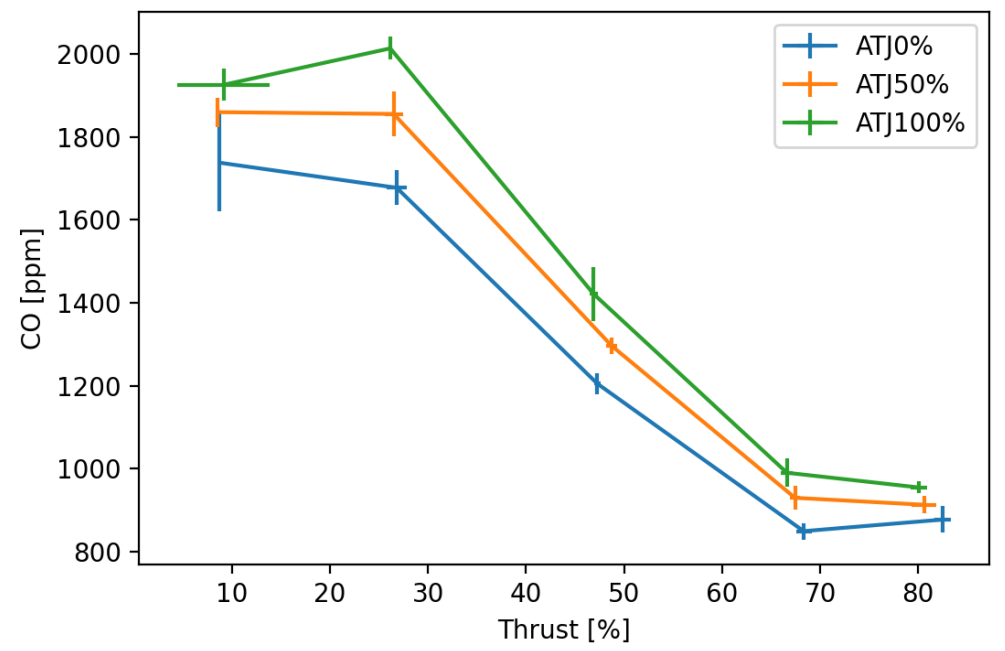

Figure 13. GTM-140/ATJ: CO emission. 


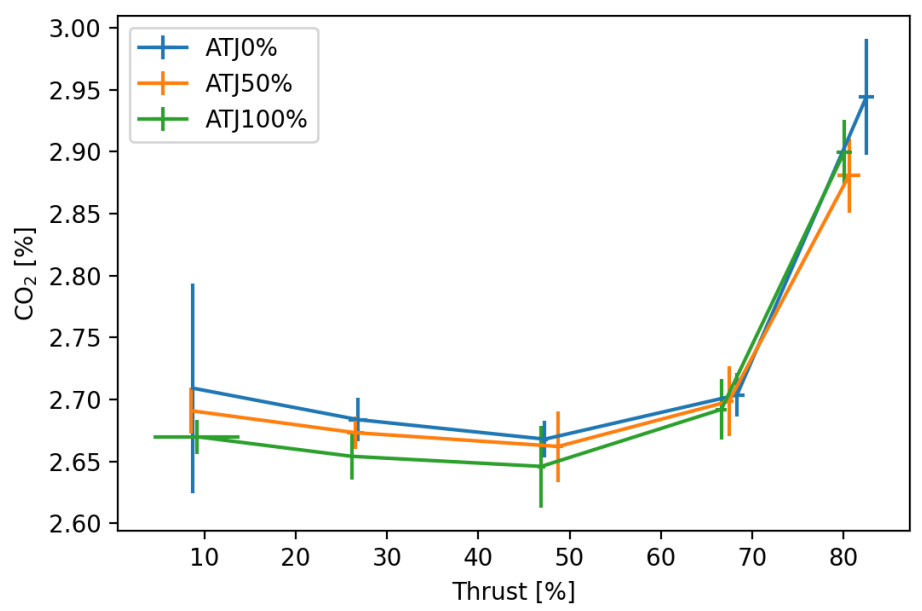

Figure 14. GTM-140/ATJ: $\mathrm{CO}_{2}$ emission.

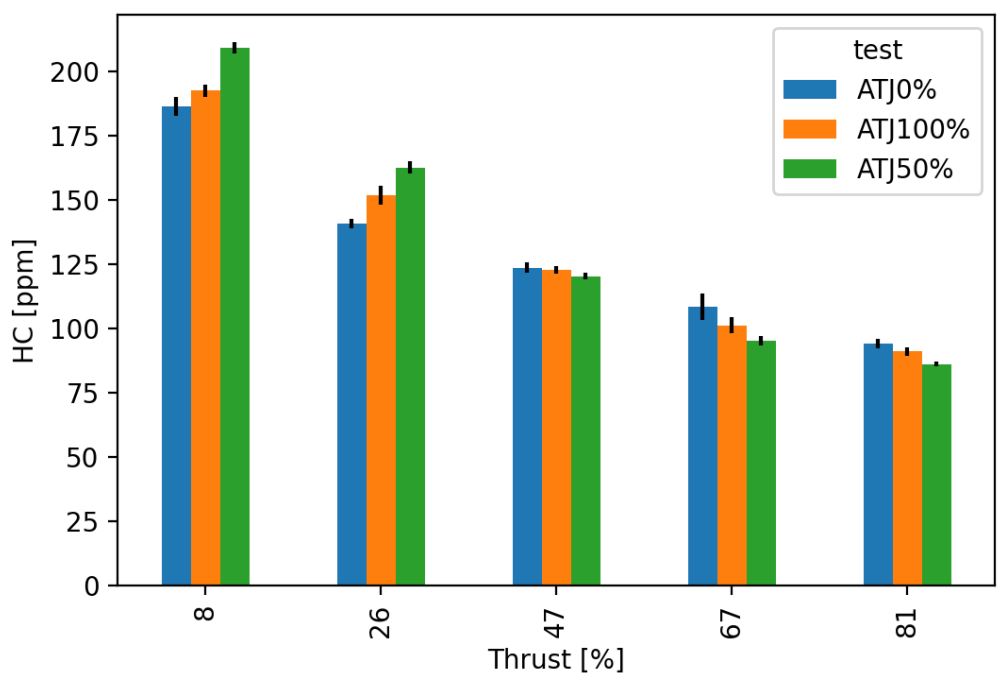

Figure 15. GTM-140/ATJ: HC emission.

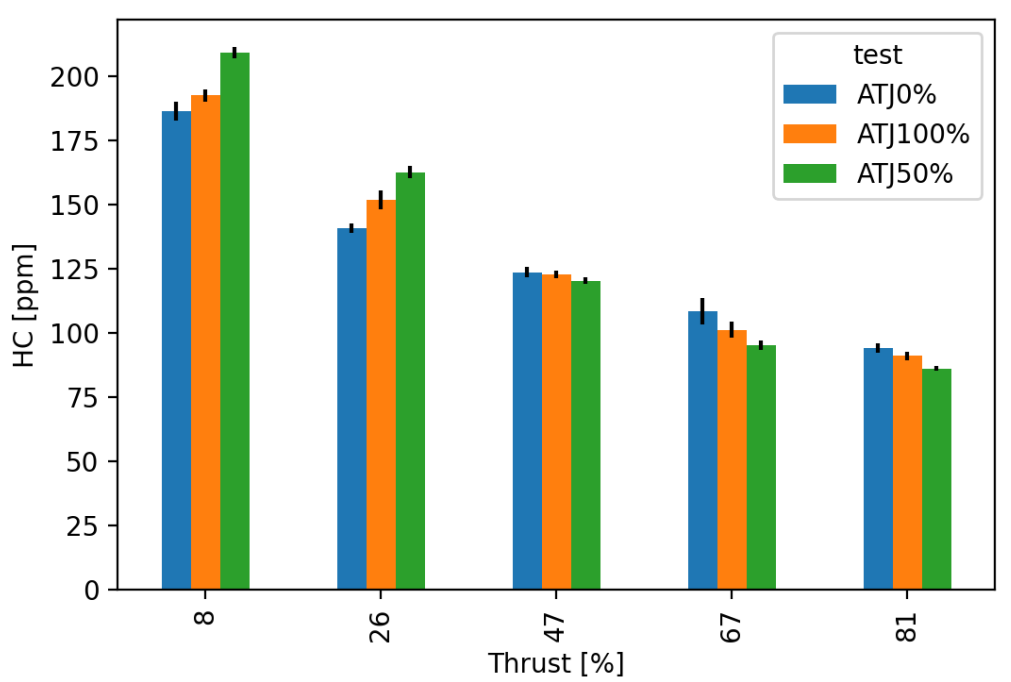

Figure 16. GTM-140/ATJ: $\mathrm{NO}_{x}$ emissions. 


\subsection{Microturbine-HEFA}

Similarly, the test-runs with HEFA blends did not affect significantly engine performance (Figures 17 and 18). Adding the HEFA component to aviation fuel causes an increase in $\mathrm{CO}$ emissions (Figure 19) in all analysed operating points while $\mathrm{CO}_{2}$ shows no clear trend (Figure 20). In terms of NO emissions, a similar direction of changes for this parameter was obtained, that is, the HEFA component generally increases NO emissions (Figure 21). The reverse trend was obtained for the emissions of hydrocarbons (HC, Figure 22). Adding HEFA component resulted in decrease in $\mathrm{HC}$ emissions in relation to pure Jet A-1 fuel.

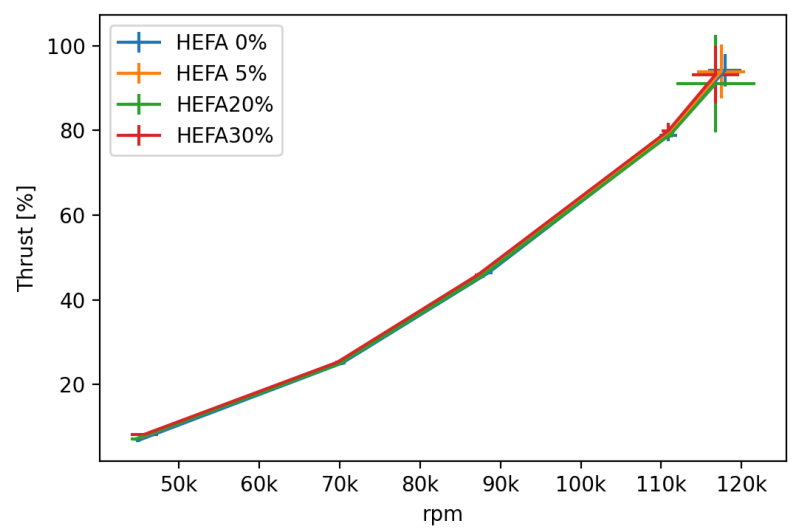

Figure 17. GTM-140/HEFA: Thrust.

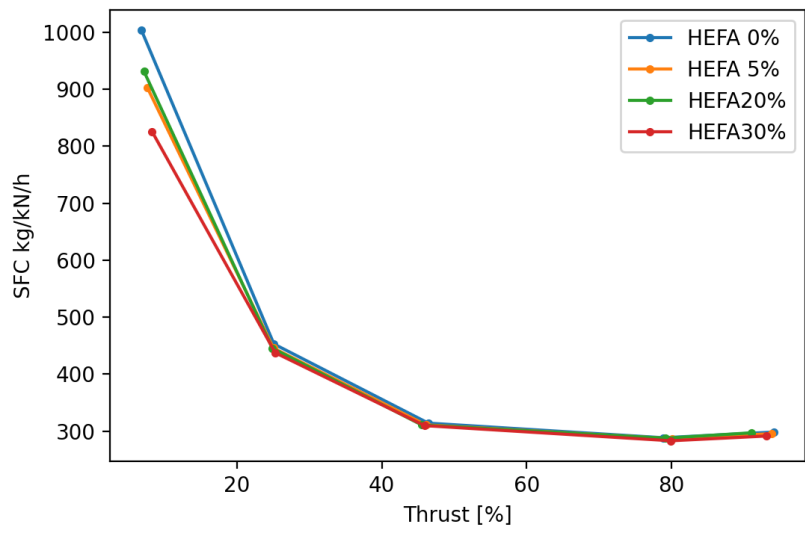

Figure 18. GTM-140/HEFA: SFC.

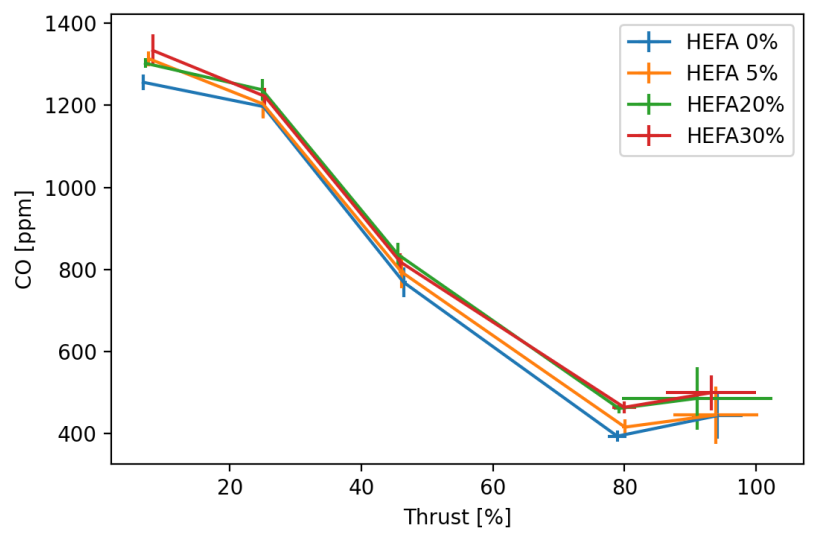

Figure 19. GTM-140/HEFA: CO emission. 


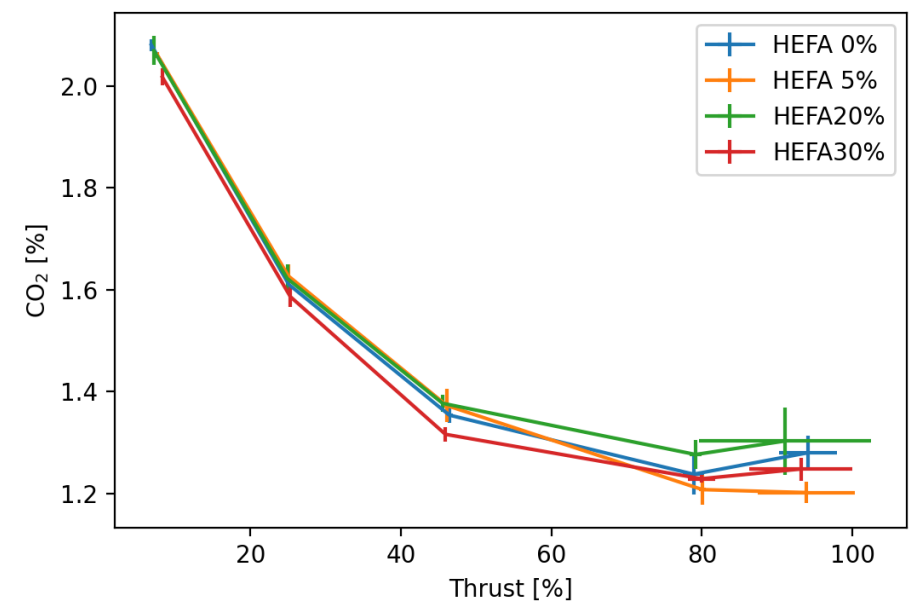

Figure 20. GTM-140/HEFA: $\mathrm{CO}_{2}$ emission.

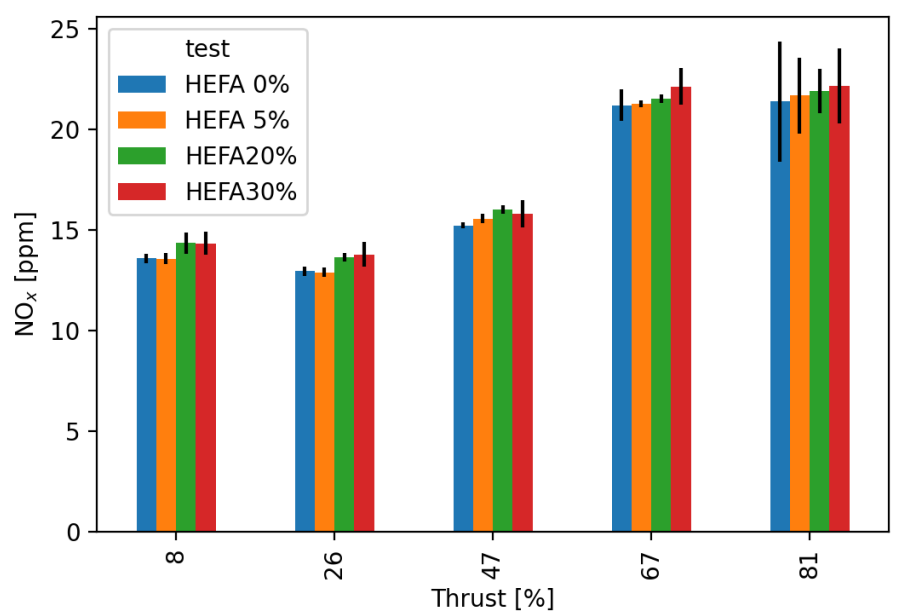

Figure 21. GTM-140/HEFA: $\mathrm{NO}_{x}$.

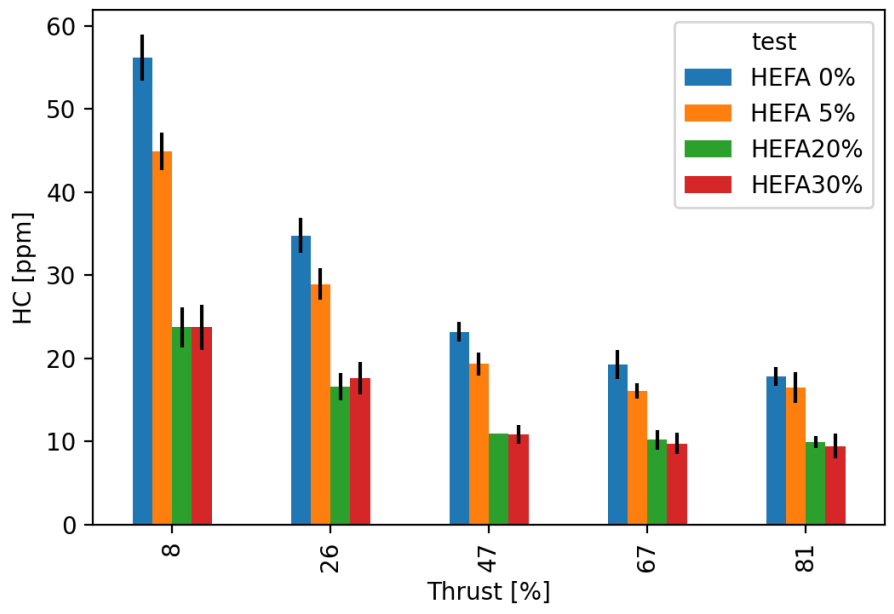

Figure 22. GTM-140/HEFA: HC emission. 


\subsection{Turbofan}

Based on the collected performance data of the DGEN 380 turbofan, it can be concluded that the relative differences in thrust (Figures 23 and 24) and fuel consumption (Figures 25 and 26) between the tests are usually less than 1\%. The biggest ones are for the take-off range, but they do not exceed 5\% (Figures A1 and A2). They are more related to the testing and engine control methods than to the used fuel blend.

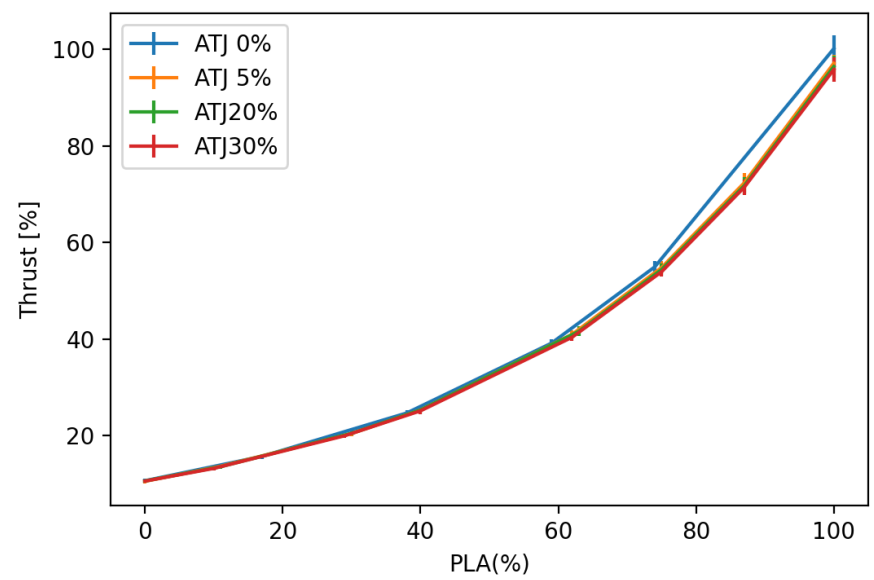

Figure 23. DGEN 380/ATJ: Thrust vs. PLA.

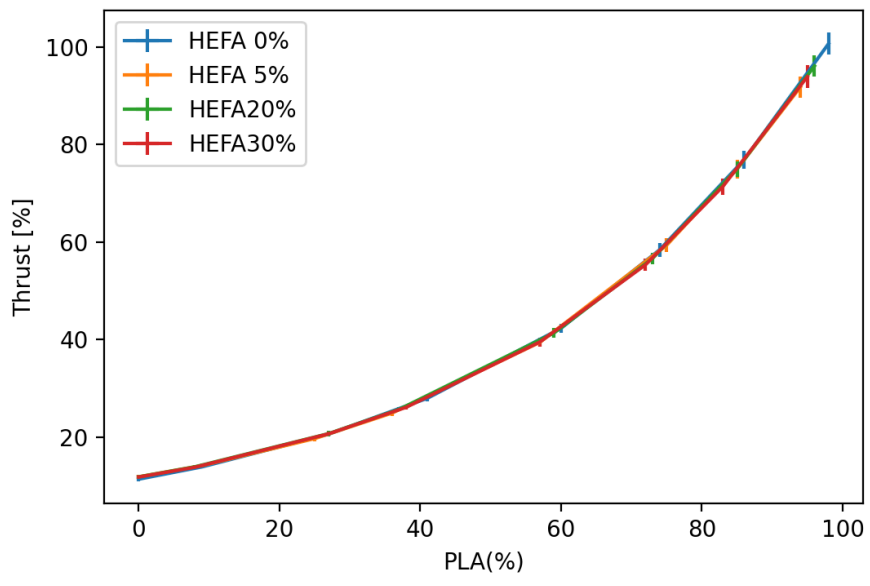

Figure 24. DGEN 380/HEFA: Thrust vs. PLA.

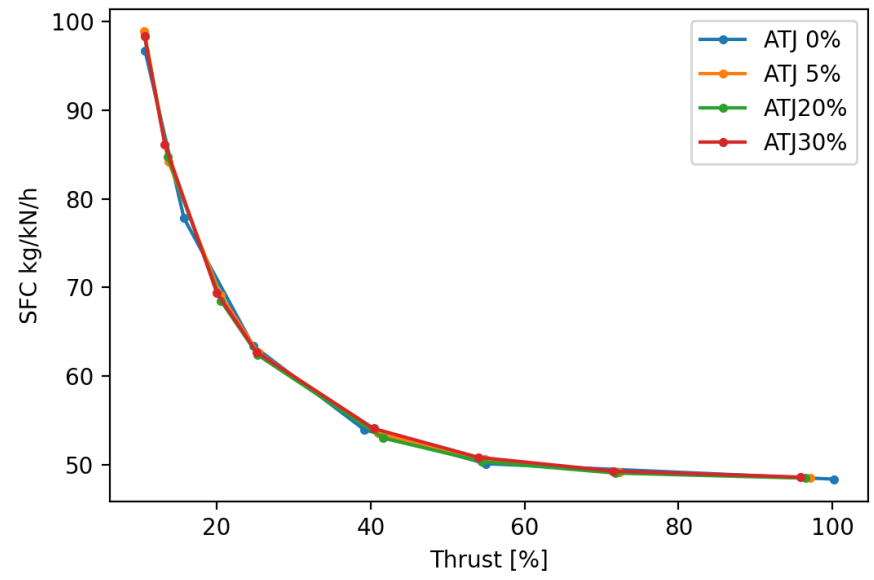

Figure 25. DGEN 380/ATJ: SFC. 


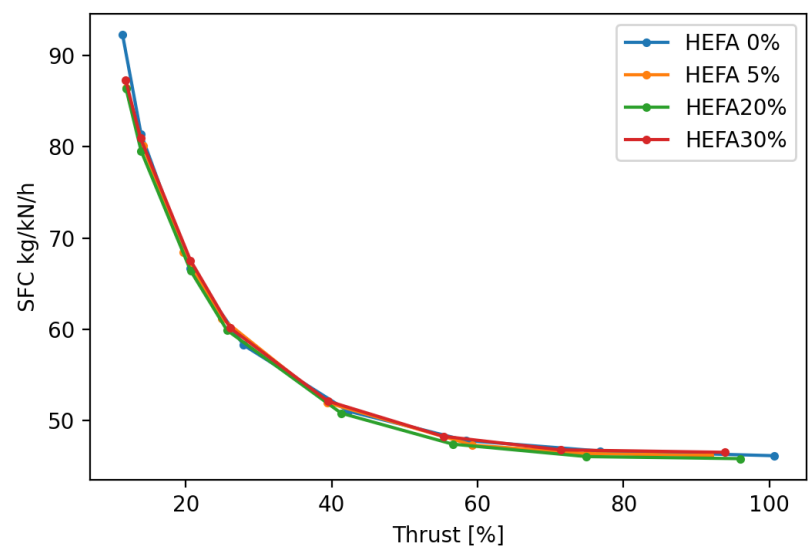

Figure 26. DGEN 380/HEFA: SFC.

When analysing the operating parameters, there is no clear trend of their change due to the use of blends with biocomponents. To associate the differences with some fuel characteristics, the model of engine and its control system is necessary. For example, when using ATJ, a slight increase in exhaust gas temperature (EGT) was observed with the increasing ratio of the biocomponent (Figure 27), but a similar trend was not observed for HEFA (Figure 28).

It is noteworthy that despite its name, PLA is proportional to rotational speed instead of thrust (Figures 23 and 24). This is the effect of FADEC operation which was not modified in this work.

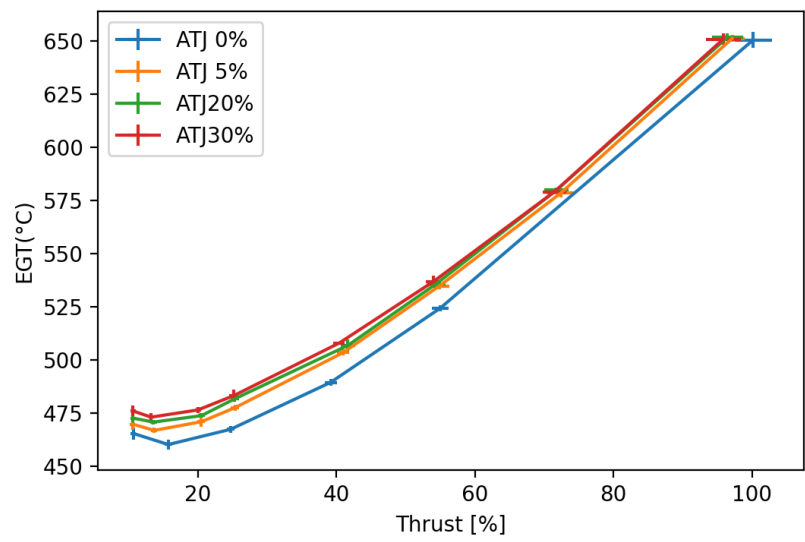

Figure 27. DGEN 380/ATJ: EGT.

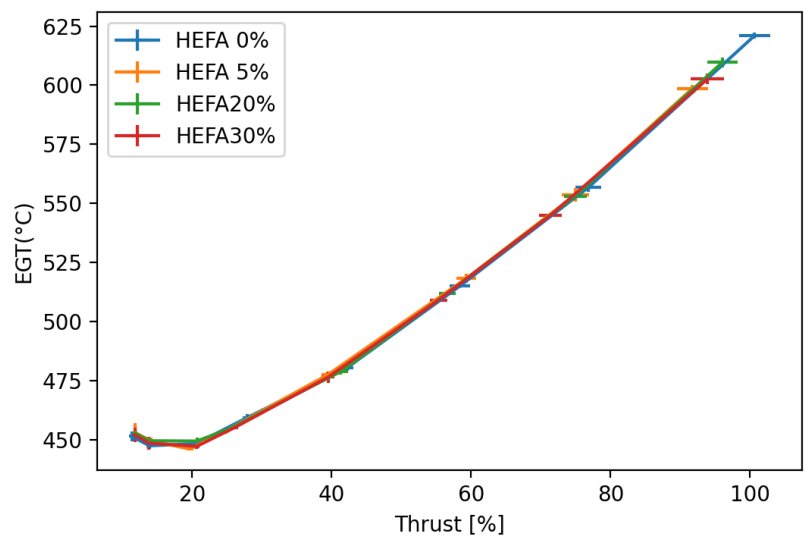

Figure 28. DGEN 380/HEFA: EGT. 
Emission-wise, adding the ATJ component to the mineral fuel resulted in a clear increase in $\mathrm{CO}$ emissions (Figure 29) and a slight increase in $\mathrm{CO}_{2}$ emissions (Figure 30) in all the analysed operating points of the DGEN 380 turbofan. The formation of CO is related to incomplete combustion of the fuel, so this process is more apparent when running on a DGEN 380 engine for blends with the ATJ component. In the case of the HEFA component, its addition resulted in a clear increase in $\mathrm{CO}$ emission (Figure 31), a slight increase in $\mathrm{CO}_{2}$ emissions (Figure 32) in all analysed operating points.

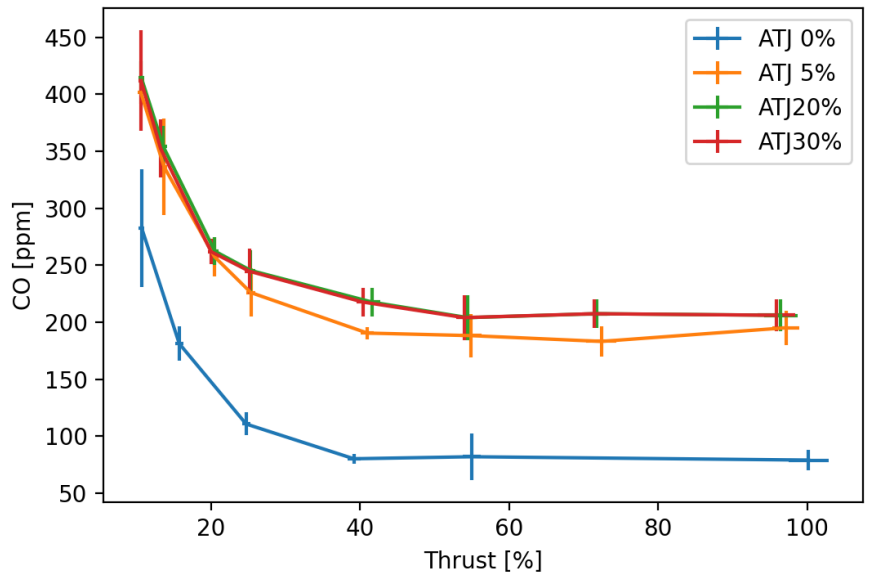

Figure 29. DGEN 380/ATJ: CO.

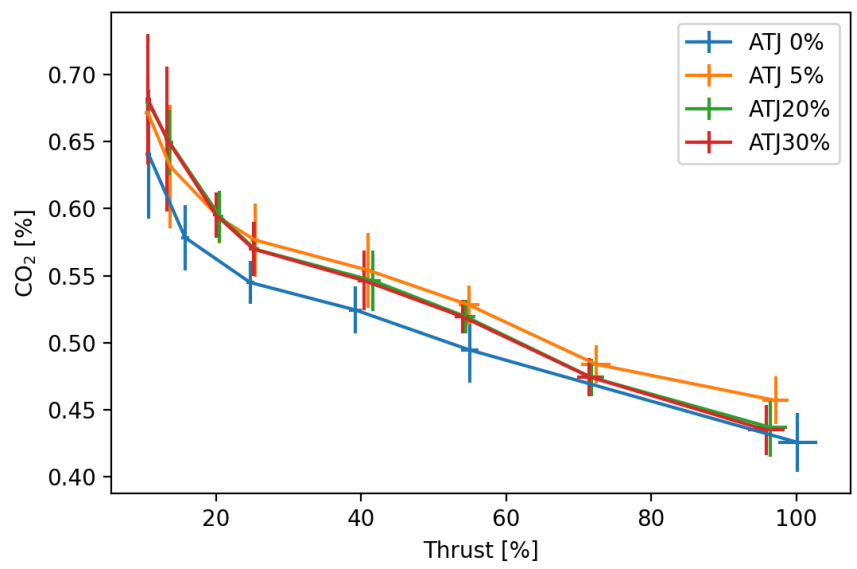

Figure 30. DGEN 380/ATJ: $\mathrm{CO}_{2}$.

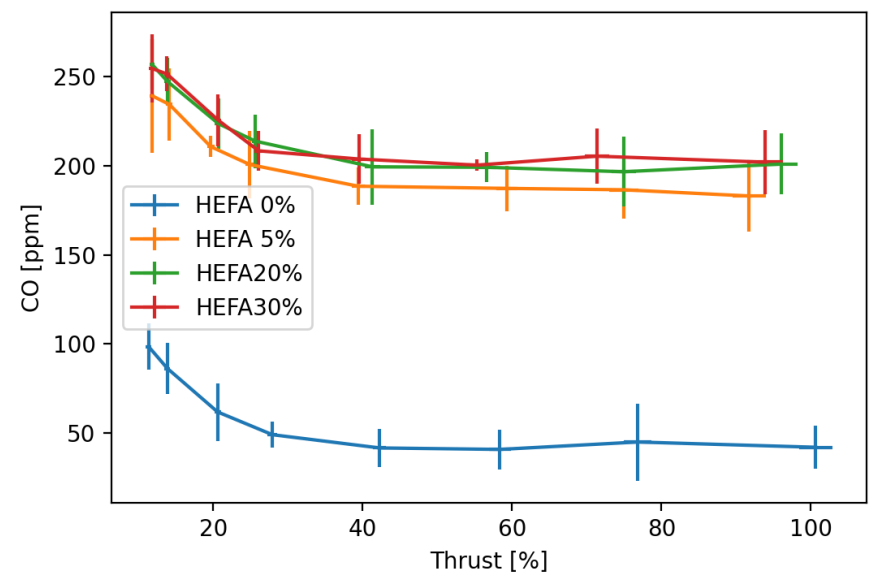

Figure 31. DGEN 380/HEFA: CO. 


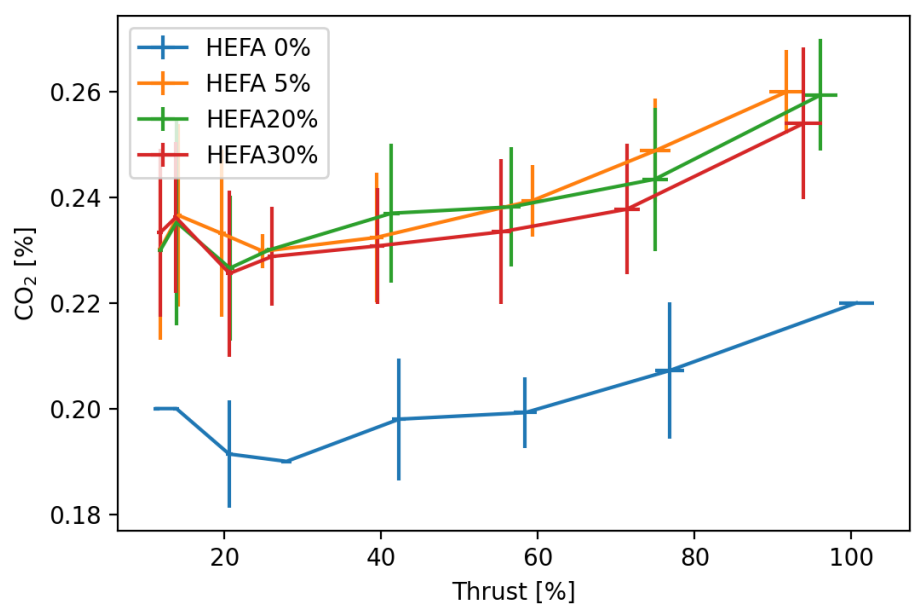

Figure 32. DGEN 380/HEFA: $\mathrm{CO}_{2}$.

Interestingly, the absolute emission values are almost twice as high for ATJ as for HEFA. Relatively low numbers of the $\mathrm{CO}_{2}$ emissions for both biofuels are due to the dilution of the exhaust gas. It corresponds to the distance between the measuring probe and the engine, which was chosen in relation to the diameter of the outlet nozzle. Placing the probe in close proximity to the engine would make the results more uncertain. In particular, directing the gas stream directly at the probe makes it impossible to take a sample, as the turbulence around the probe caused by high dynamic pressure disturb the measurements.

A significant increase in CO emissions observed for the DGEN380 engine for both biocomponents has not been completely explained. Different gas dilution for ATJ and HEFA tests is addressed by relating emissions to the $\mathrm{CO}_{2}$ level which is equivalent to the known method of correcting emission to $15 \%$ oxygen [34]. The obtained relation of $\mathrm{CO}$ to $\mathrm{CO}_{2}$ behaves well (Figures 33 and 34) and confirms that the observed $\mathrm{CO}$ increase is not a simple measurement error.

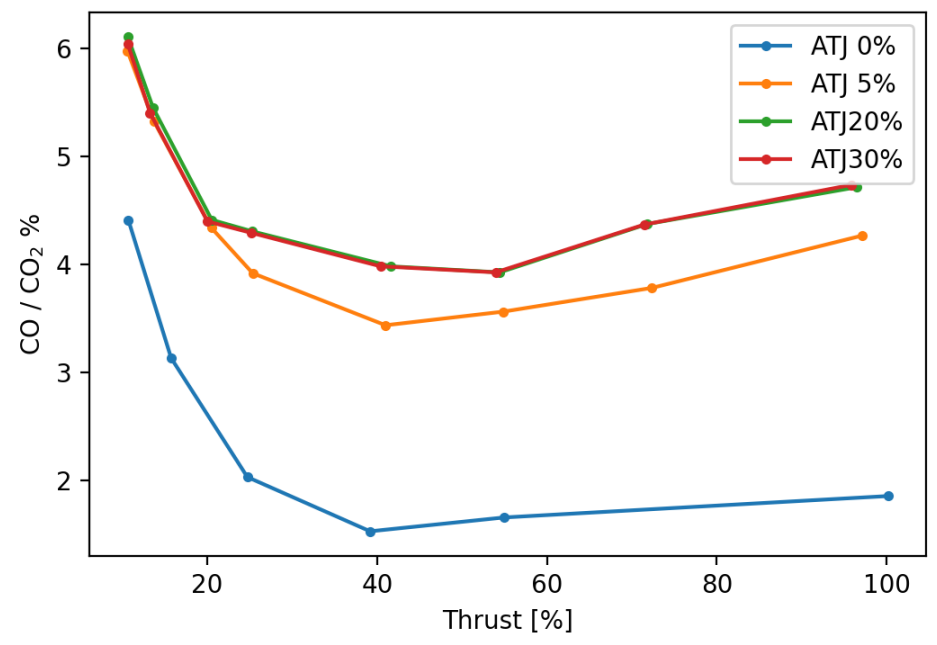

Figure 33. DGEN 380/ATJ: CO vs. $\mathrm{CO}_{2}$. 


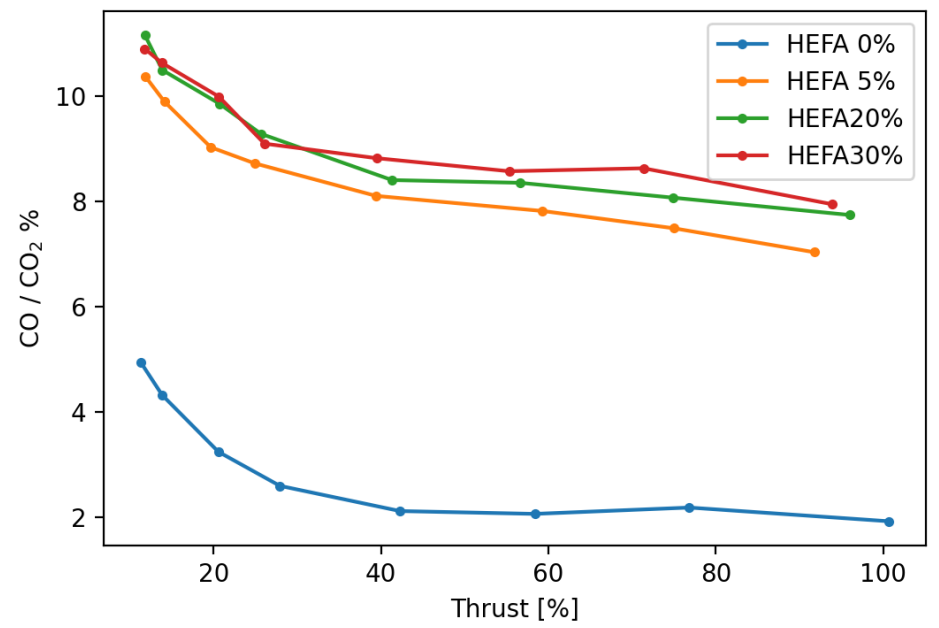

Figure 34. DGEN 380/HEFA: CO vs. $\mathrm{CO}_{2}$.

In general, $\mathrm{CO}$ emissions are related to incomplete combustion and dominate at low speeds. In this case, the increase was approximately $150 \mathrm{ppm}$ for any speed and for all blends including biocomponents. This engine has a reverse flow combustor which is not typical for turbofans but the CFD simulations confirmed the effective combustion of bioethanol and moderate emissions [35]. Custom design of the combustor may have an impact, but should not increase $\mathrm{CO}$ emission so much as a result of adding tiny amounts of biocomponent (5\%).

\section{Conclusions}

For both engines, the analysis of engine performance parameters showed that the tested blends differ so little from the mineral fuel that their impact on the engine operating parameters is limited, and their use does not carry the risk of a significant decrease in aircraft performance or increase in fuel consumption.

The experimental emissions results for the DGEN 380 turbofan have never been published elsewhere. In relation to the previous tests of the microturbine carried out in ITWL, the emissions for the ATJ biocomponent and intermediate ratios of HEFA were studied for the first time. In addition, the Semtech analyzer of a class better resolution was used. Particulate emissions were also measured, but their analysis will be the subject of a separate publication.

It was found that increasing the content of biocomponents causes a noticeable increase in the emission of $\mathrm{CO}$ and some other gasses $\left(\mathrm{HC}\right.$ and $\left.\mathrm{NO}_{x}\right)$, which should not, however, worsen the working conditions of the ground personnel. Deeper understanding of the effects of fuel blends on engine performance and emissions requires complex engine models, describing, in particular, its combustor and control system.

The use of small engines, and especially microturbines, for alternative fuels and emissions testing is debatable. They are not scaled large engines, but their structure differ significantly, especially in terms of combustors. Heat cycle losses and SFC are much higher due to relatively large tip clearances. Although the overall emission trends are maintained, the attempt to scale the results from the microturbine to a larger engine was partially successful.

The acquired data will be used to develop an engine emissivity model to predict gas emissions. Statistical methods and the analytical combustion model seem to be suitable for linking the thermophysical parameters of the fuel with the operating parameters and emissions of engines of a basic structure. 
Author Contributions: Conceptualization: B.G., T.B., A.Ł. and J.M.; Data curation: R.P., B.G. and R.J.; Investigation: R.P., B.G., A.Ł. and R.J.; Methodology, R.P., B.G., T.B., A.Ł. and R.J.; Project administration: R.P.; Software: R.P.; Supervision: R.P., T.B. and J.M.; Validation: B.G., T.B., J.M. and R.J.; Visualization: R.P. and A.Ł.; Writing-original draft: R.P. and B.G.; Writing-review \& editing, R.P. All authors have read and agreed to the published version of the manuscript.

Funding: This research received no external funding.

Data Availability Statement: The data presented in this study are available on request from the corresponding author.

Acknowledgments: Our special thanks are extended to Aleksander Olejnik from the Military University of Technology in Warsaw for providing the DGEN 380 turbofan and Anna Mikołajczyk for performing engine tests. We also wish to thank Jacek Pielecha from the Poznań University of Technology for for his contribution to emission measurements and substantive support.

Conflicts of Interest: The authors declare no conflict of interest.

\section{Abbreviations}

The following abbreviations and symbols are used in this manuscript:

ATJ Alcohol-to-Jet

CFD computational fluid dynamics

$\mathrm{CO}$ carbon monoxide

$\mathrm{CO}_{2} \quad$ carbon dioxide

EASN European Aeronautics Science Network

EGT exhaust gas temperature

FADEC full authority digital engine control

FID flame-ionizing detector

GSP Gas turbine Simulation Program

HC hydrocarbons

HEFA Hydroprocessed Esters and Fatty Acids

ICAO International Civil Aviation Organization

ITWL The Air Force Institute of Technology in Warsaw

LTO landing and take-off (cycle)

NDIR non-dispersive infrared (sensor)

NDUV non-dispersive ultraviolet (analyzer)

$\mathrm{NO}_{x} \quad$ nitrogen oxides

PLA power lever angle

PM particulate mater

rpm revolutions per minute

SAF sustainable aviation fuel

SFC specific fuel consumption

SPK synthetic paraffinic kerosene

UCO used cooking oil

WESTT Whole Engine Simulator Turbine Technology 


\section{Appendix A}

Figures A1 and A2 show the SFC difference between blends and the Jet A-1 fuel.

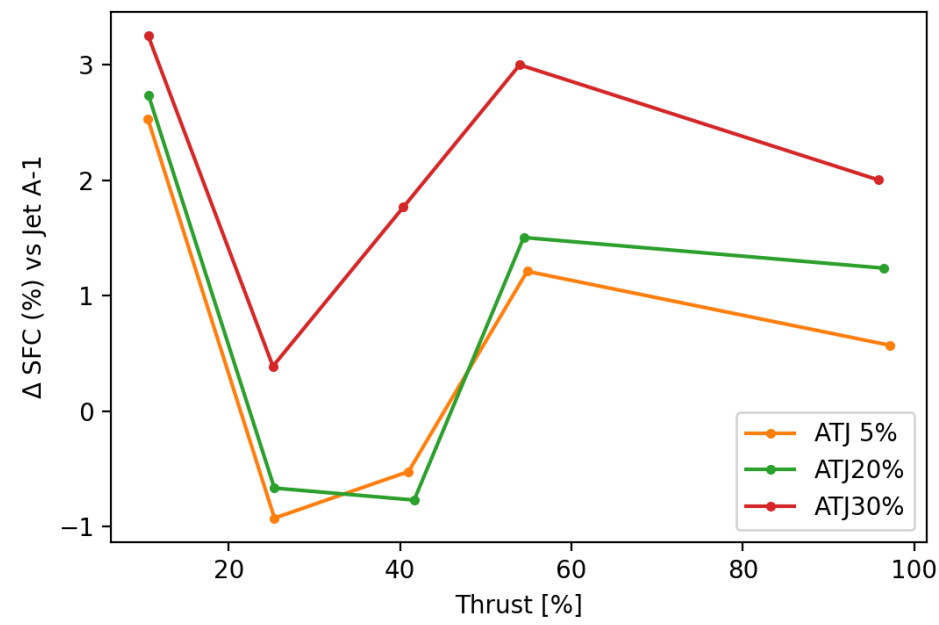

Figure A1. DGEN 380/ATJ: SFC changes.

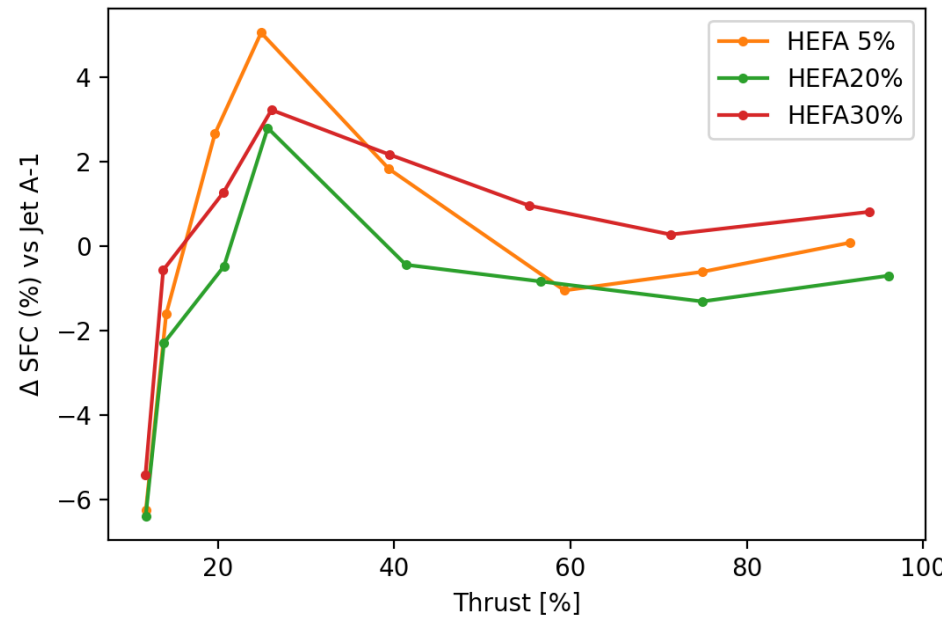

Figure A2. DGEN 380/HEFA: SFC changes.

\section{References}

1. Lieuwen, T.C.; Yang, V. Gas Turbine Emissions; Cambridge University Press: Cambridge, UK, 2013; Volume 38.

2. Merkisz, J.; Markowski, J.; Pielecha, J. Selected Issues in Exhaust Emissions from Aviation Engines; NOVA Science: New York, NY, USA, 2014; p. 209.

3. Military User's Guide for the Certification of Aviation Platforms on Synthetic Jet Fuels TR-AVT-225; NATO Science and Technology Organization: Neuilly-sur-Seine, France, 2018.

4. Jasinski, R. Mass and number analysis of particles emitted during aircraft landing. E3S Web Conf. 2018, 44, 00057. [CrossRef]

5. Chwaleba, A.; Olejnik, A.; Rapacki, T.; Tuśnio, N. Analysis of capability of air pollution monitoring from an unmanned aircraft. Aviation 2014, 18, 13-19. [CrossRef]

6. Jasiński, R.; Markowski, J.; Pielecha, J. Probe Positioning for the Exhaust Emissions Measurements. Procedia Eng. 2017, 192, 381-386. [CrossRef]

7. Archilla, V.; Hormigo, D.; Sánchez-García, M.; Raper, D. AVIATOR-Assessing aViation emission Impact on local Air quality at airports: Towards Regulation. In Proceedings of the MATEC Web of Conferences; EDP Sciences: Les Ulis, France, 2019; Volume 304, p. 02023. [CrossRef]

8. Gawron, B.; Białecki, T.; Janicka, A.; Górniak, A.; Zawiślak, M. An innovative method for exhaust gases toxicity evaluation in the miniature turbojet engine. Aircr. Eng. Aerosp. Technol. 2017, 89, 757-763. [CrossRef]

9. Janicka, A.; Zawiślak, M.; Zaczyńska, E.; Czarny, A.; Górniak, A.; Gawron, B.; Białecki, T. Exhausts toxicity investigation of turbojet engine, fed with conventional and biofuel, performed with aid of BAT-CELL method. Toxicol. Lett. 2017, 280, S202. [CrossRef] 
10. Gawron, B.; Białecki, T.; Janicka, A.; Zawiślak, M.; Górniak, A. Exhaust toxicity evaluation in a gas turbine engine fueled by aviation fuel containing synthesized hydrocarbons. Aircr. Eng. Aerosp. Technol. 2020, 92, 60-66. [CrossRef]

11. Habib, Z.; Parthasarathy, R.; Gollahalli, S. Performance and emission characteristics of biofuel in a small-scale gas turbine engine. Appl. Energy 2010, 87, 1701-1709. [CrossRef]

12. Chiariello, F.; Allouis, C.; Reale, F.; Massoli, P. Gaseous and particulate emissions of a micro gas turbine fuelled by straight vegetable oil-kerosene blends. Exp. Therm. Fluid Sci. 2014, 56, 16-22. [CrossRef]

13. Badami, M.; Nuccio, P.; Pastrone, D.; Signoretto, A. Performance of a small-scale turbojet engine fed with traditional and alternative fuels. Energy Convers. Manag. 2014, 82, 219-228. [CrossRef]

14. Allouis, C.; Amoresano, A.; Capasso, R.; Langella, G.; Niola, V.; Quaremba, G. The impact of biofuel properties on emissions and performances of a micro gas turbine using combustion vibrations detection. Fuel Process. Technol. 2018, 179, 10-16. [CrossRef]

15. Kluiters, S.C.A.; Visser, W.P.J.; Rademaker, E.R. A New Combustor and Emission Model for the Gas Turbine Simulation Program GSP; Technical Report; NLR: Amsterdam, The Netherlands, 2014.

16. Gaspar, R.M.; Sousa, J.M. Impact of alternative fuels on the operational and environmental performance of a small turbofan engine. Energy Convers. Manag. 2016, 130, 81-90. [CrossRef]

17. GasTurb GmbH. GasTurb 13 Design and Off-Design Performance of Gas Turbines; GasTurb GmbH: Aachen, Germany, 2018.

18. Mador, R.; Roberts, R. A pollutant emissions prediction model for gas turbine combustors. In Proceedings of the 10th Propulsion Conference, Lake Tahoe, NV, USA, 31 October-2 November 1973; American Institute of Aeronautics and Astronautics: Reston, VA, USA, 1974. [CrossRef]

19. Rizk, N.; Mongia, H. Emissions predictions of different gas turbine combustors. In Proceedings of the 32nd Aerospace Sciences Meeting and Exhibit, Reno, NV, USA, 10-13 January 1994; American Institute of Aeronautics and Astronautics: Reston, VA, USA, 1994. [CrossRef]

20. Kulczycki, A.; Kaźmierczak, U. Method of preliminary evaluation of biocomponents influence on the process of biofuels combustion in aviation turbine engines. J. KONES 2017, 24, 83-90. [CrossRef]

21. Dolmatov, D.; Hajivand, M. On Low-Emission Annular Combustor Based on Designing of Liner Air Admission Holes. NTU KhPI Bull. Power Heat Eng. Process. Equip. 2018, 13, 83-94. [CrossRef]

22. EASA. Introduction to the ICAO Engine Emissions Databank Background; EASA: Köln, Germany, 2018.

23. Allaire, D.L.; Waitz, I.A.; Willcox, K.E. A comparison of two methods for predicting emissions from aircraft gas turbine combustors. Proc. ASME Turbo Expo 2007, 2, 899-908. [CrossRef]

24. Filippone, A.; Bojdo, N. Statistical model for gas turbine engines exhaust emissions. Transp. Res. Part D Transp. Environ. 2018, 59, 451-463. [CrossRef]

25. ASTM D7566-20b, Standard Specification for Aviation Turbine Fuel Containing Synthesized Hydrocarbons; Technical Report; ASTM International: West Conshohocken, PA, USA, 2020. [CrossRef]

26. Gawron, B.; Białecki, T. Measurement of exhaust gas emissions from miniature turbojet engine. Combust. Engines 2016, 167, 58-63. [CrossRef]

27. Gawron, B.; Białecki, T. Impact of a Jet A-1/HEFA blend on the performance and emission characteristics of a miniature turbojet engine. Int. J. Environ. Sci. Technol. 2018, 15, 1501-1508. [CrossRef]

28. Gawron, B.; Białecki, T.; Janicka, A.; Suchocki, T. Combustion and emissions characteristics of the turbine engine fueled with HeFA blends from different feedstocks. Energies 2020, 13, 1277. [CrossRef]

29. Gawron, B.; Białecki, T. The laboratory test rig with miniature jet engine to research aviation fuels combustion process. J. Konbin 2015, 36, 79-90. [CrossRef]

30. ICAO CAEP10; ICAO Steering Group. Environmental Technical Manual, Volume II Procedures for the Emissions Certification of Aircraft Engines, Second Edition-2014 + Revisions_Feb 2016; ICAO: Montreal, QC, Canada, 2016; Volume II.

31. Olzak, B.; Szymczak, J.; Szczepankowski, A. Gaseous erosion and corrosion of turbines. J. Pol. CIMAC 2007, 2, 199-204.

32. Szczepankowski, A.; Szymczak, J.; Przysowa, R. The Effect of a Dusty Environment upon Performance and Operating Parameters of Aircraft Gas Turbine Engines. In STO-MP-AVT-272 Impact of Volcanic Ash Clouds on Military Operations; Jackson, R., Ed.; NATO Science and Technology Organization: Neuilly-sur-Seine, France, 2017; pp. 1-13. [CrossRef]

33. Dzięgielewski, W.; Gawron, B. Badanie przydatności biokomponentów I generacji do paliw stosowanych do turbinowych silników lotniczych (Suitability of 1st generation biocomponents for fuelling aircraft gas-turbine engines). Res. Work. Air Force Inst. Technol. 2018, 30, 221-234. [CrossRef]

34. Output-Based Regulations: A Handbook for Air Regulators; Technical Report; U.S. Environmental Protection Agency Combined Heat and Power Partnership: Washington, DC, USA, 2004.

35. Pi, J.; Fu, J.; Jiang, S.; Kong, Q.G. Properties of the small-size turbofan engine burning biofuels. Biofuels 2017, 8, 579-583. [CrossRef] 